\title{
Growth of young Tabebuia aurea seedlings under irrigation with wastewater from fish farming
}

\author{
José R. de S. Pinto ${ }^{1}$, Rômulo M. O. de Freitas ${ }^{2}$, Tiago de S. Leite ${ }^{3}$, \\ Francisco de A. de Oliveira' ${ }^{4}$, Hugo Ferreira ${ }^{3}$ \& Moadir de S. Leite ${ }^{3}$ \\ ${ }^{1}$ Universidade Federal Rural do Semi-Árido/Programa de Pós-Graduação em Fitotecnia. Mossoró, RN. E-mail: rivanildo.ufersa@gmail.com \\ ${ }^{2}$ Instituto Federal de Educação/Ciência e Tecnologia Baiano. Valença, BA. E-mail: romulomagno_23@hotmail.com (Corresponding author) \\ ${ }^{3}$ Universidade Federal Rural do Semi-Árido/Departamento de Ciências Vegetais. Mossoró, RN. E-mail: tiago.desousaleite@student.adelaide.edu.au; \\ hugopinheiro35@gmail.com; moadir@outlook.com \\ ${ }^{4}$ Universidade Federal Rural do Semi-Árido/Departamento de Ciências Ambientais e Tecnológicas. Mossoró, RN. E-mail: thikaoamigao@ufersa.edu.br
}

Key words:

water reuse

seedling production

salinization

reforestation

\begin{abstract}
A B S T R A C T
This study aimed to evaluate the growth of young Tabebuia aurea seedlings irrigated with different concentrations of wastewater from fish farming. The experiment was conducted in a seedling nursery, from June to August 2013. The treatments consisted of five concentrations of wastewater from fish farming diluted in freshwater $(0,25,50,75$ and $100 \%$ of wastewater). Plant height, stem diameter and plant height/stem diameter ratio were evaluated every 15 days to verify the effects of treatments on seedlings growth. At the end of the experiment, individual leaf area, leaf area, leaf dry matter, stem dry matter, root dry matter, total dry matter and Dickson quality index were also evaluated. The reuse of wastewater from fish farming diluted at concentrations of 25 and $50 \%$ in freshwater is a viable alternative in the production of Tabebuia aurea seedlings. However, higher concentrations hinder the production of seedlings of this species.
\end{abstract}

\section{Palavras-chave:}

reutilização de água produção de mudas

salinização

reflorestamento

\section{Crescimento de mudas jovens de craibeira sob irrigação com água residuária da piscicultura}

\section{R E S U M O}

Objetivou-se, neste trabalho, avaliar o crescimento de mudas jovens de craibeira (Tabebuia aurea) irrigadas com diferentes concentrações de água residuária da piscicultura. $\mathrm{O}$ experimento foi conduzido em viveiro de produção de mudas, entre junho e agosto de 2013. Os tratamentos foram compostos por cinco concentrações de água residuária da piscicultura diluídas em água de abastecimento (0,25, 50, 75 e 100\% de água residuária). Foram realizadas avaliações quinzenais para verificação dos efeitos dos tratamentos no crescimento das mudas avaliando-se o comprimento da parte aérea, diâmetro do colo e relação comprimento da parte aérea/diâmetro do colo. A área foliar unitária, área foliar, matéria seca das folhas, caules, raízes e total e índice de qualidade de Dickson também foram avaliados ao término do experimento. O reúso de água residuária da piscicultura diluída nas concentrações de 25 a 50\% é uma alternativa viável para irrigação de mudas de craibeira sendo que concentrações superiores inviabilizaram a produção de mudas dessa espécie.

Ref. 065-2015 - Received 22 May, 2015 • Accepted 4 Apr, 2016 • Published 28 Apr, 2016 


\section{INTRODUCTION}

The reduction in the availability of water resources and the contamination of surface and underground water sources point to the tendency of rational use of the water resource (Hussar et al., 2005). Water reuse is an emerging alternative in regions of low water availability. The use of water of lower quality, besides meeting part of plant water demand, can also provide many of the nutrients necessary for the plants (Rocha et al., 2014).

The necessity of recovery of degraded areas stimulates a constant search for remediation strategies, such as reforestation; for this, it is necessary to install seedling production nurseries, which promote high water consumption and generate problems in regions with limited water resources. Thus, the use of wastewater in seedlings production is essential, since it can substitute the use of treated or potable water. Besides serving as water and nutritional supply to plants, its use decreases the environmental impact caused by the discharge of waters rich in nutrients in the rivers (Castro et al., 2005). However, studies on wastewater are incipient for the irrigation of forest species.

Bezerra \& Fideles Filho (2009) explain that one must be careful with the use of wastewater, avoiding the harmful effects on the environment, such as soil salinization and contamination of groundwater. Oliveira et al. (2009) claim that fish-farming effluent can be considered as one alternative for irrigation, because of its high concentration of nutrients. However, besides these nutrients, it also has high concentration of salts, which means high electrical conductivity and generates a saline effect, limiting its reuse in plant production (Oliveira et al., 2009).

Many authors have reported salinity effects on the initial growth of arboreal species (Silva et al., 2000; Sousa et al., 2011). Nevertheless, there are not many studies involving the reuse of fish-farming saline effluent for the production of seedlings of forest species. Therefore, studies on the use of these waters are of great importance, specially due to the high diversity in the tolerance of plant species to saline stress (Holanda et al., 2007).

Tabebuia aurea, also known as 'craibeira', is a plant from the Bignoniaceae family, which occurs in the Caatinga biome. Due to its economic and ecological characteristics, this species has been indicated for reforestation programs, especially in riparian forests of regions with low rainfall regime (Lorenzi, 2000). In this context, considering the importance of forest activities and given the lack of studies on the reuse of wastewater in the production of forest seedlings, this study aimed to evaluate the growth of young Tabebuia aurea seedlings irrigated with different concentrations of fish-farming wastewater.

\section{Material AND Methods}

The experiment was carried out at the Federal Rural University of the Semi-arid Region (UFERSA) from June to
August 2013, in the city of Mossoró-RN, Brazil (05 $15^{\prime}$ S; $37^{\circ}$ $20^{\prime} \mathrm{W} ; 18 \mathrm{~m}$ ) with mean annual temperature around $27.5^{\circ} \mathrm{C}$, relative air humidity of $68.9 \%$, mean annual cloudiness of 4.4 tenths and mean annual rainfall of $673.9 \mathrm{~mm}$, with hot and dry climate (Carmo Filho et al., 1991). Inside the nursery (50\% shading), the mean temperature was $28.5^{\circ} \mathrm{C}$ and mean relative air humidity was $68.3 \%$ during the experiment.

The experiment was set in a randomized complete block design, in a split-plot scheme, with four replicates and four plants per experimental unit. In the plots, the treatments consisted of five concentrations of wastewater diluted in supply freshwater $(0,25,50,75$ and $100 \%$ of wastewater) and, in the subplot, periods of evaluation $(0,15,30,45$ and 60 days after transplantation - DAT). The wastewater was supplied by the aquiculture sector of the UFERSA, Campus of Mossoró, and the physical-chemical characteristics of the different irrigation waters obtained after dilution are shown in Table 1.

Tabebuia aurea seeds were collected and benefitted in the same locality of the experiment and sowing was performed on low-density polystyrene trays containing substrate of coconut fiber. During germination, daily irrigations were performed using water from the local water supply system. At 21 days, when the seedlings showed two pairs of fully expanded true leaves, they were transplanted to 0.9 -L polyethylene plastic bags, using soil from the region as a substrate. At this moment, the application of the treatments started and each plot began to be daily irrigated, with $200 \mathrm{~mL}$.

The physical analysis of the soil used as substrate showed the following granulometry: coarse sand $=0.66 \mathrm{~kg} \mathrm{~kg}^{-1}$; fine sand $=0.21 \mathrm{~kg} \mathrm{~kg}^{-1}$; total sand $=0.87 \mathrm{~kg} \mathrm{~kg}^{-1}$; silt $=0.09 \mathrm{~kg}$ $\mathrm{kg}^{-1}$; and clay $=0.04 \mathrm{~kg} \mathrm{~kg}^{-1}$. Soil chemical analysis showed the following results: $\mathrm{pH}$ (water) $=8.28 ; \mathrm{EC}=0.13 \mathrm{dS} \mathrm{m} \mathrm{m}^{-1}$; organic matter $=11.36$ and $\mathrm{N}=0.35 \mathrm{~g} \mathrm{~kg}^{-1} ; \mathrm{P}=25.8, \mathrm{~K}^{+}=$ 98.85 and $\mathrm{Na}^{+}=95 \mathrm{mg} \mathrm{dm}{ }^{-3} ; \mathrm{Ca}^{2+}=3.2$ and $\mathrm{Mg}^{2+}=0.48 \mathrm{cmol}_{c}$ $\mathrm{dm}^{-3} ; \mathrm{Cu}=0.06, \mathrm{Fe}=2.2, \mathrm{Mn}=11.3$ and $\mathrm{Zn}=3.63 \mathrm{mg} \mathrm{dm}^{-3}$.

Biweekly evaluations were performed to observe the effects of the treatments on the growth of seedlings, based on shoot length (ShL), stem diameter (StD) and shoot length/ stem diameter ratio (ShL/StD) (Carneiro, 1995). At 60 DAT, the following variables were also evaluated: individual leaf area (ILA), leaf area (LA), leaf dry matter (LDM), stem dry matter (SDM), root dry matter (RDM) and total dry matter (TDM), as well as Dickson quality index (DQI), following the recommendations of Dickson et al. (1960).

Leaf area was measured through the corrected leaf disc method (Souza et al., 2012). Thus, 10 discs with previously known area $\left(1.72 \mathrm{~cm}^{2}\right)$ were randomly removed from each plot for the determination of dry weight. LA per plant was then calculated using a simple rule of three based on the area,

Table 1. Physico-chemical characterization of the irrigation waters used in the experiment

\begin{tabular}{|c|c|c|c|c|c|c|c|c|c|c|c|}
\hline \multirow{2}{*}{ Treatments } & \multirow{2}{*}{ pH } & \multirow{2}{*}{$\begin{array}{c}E C \\
\left(\mathrm{dS} \mathrm{m}^{-1}\right)\end{array}$} & \multicolumn{3}{|c|}{ Anions $\left(\mathrm{mmol}_{\mathrm{c}} \mathrm{L}^{-1}\right)$} & \multicolumn{4}{|c|}{ Cations $\left(\mathrm{mmol}_{\mathrm{c}} \mathrm{L}^{-1}\right)$} & \multirow{2}{*}{$\begin{array}{c}\text { SAR* }^{*} \\
\left(\mathrm{mmol} \mathrm{L}^{-1}\right)^{0.5}\end{array}$} & \multirow{2}{*}{ Classification } \\
\hline & & & $\mathrm{CO}_{3}$ & $\mathrm{HCO}_{3}$ & $\mathrm{Cl}$ & $\mathrm{Mg}$ & $\mathrm{Ca}$ & $\mathrm{Na}$ & K & & \\
\hline T1 & 7.85 & 0.54 & 1.10 & 2.95 & 2.50 & 0.93 & 0.63 & 9.75 & 10.35 & 11.04 & C2S2 \\
\hline $\mathrm{T} 2$ & 8.25 & 1.56 & 1.20 & 2.80 & 8.90 & 3.59 & 3.31 & 22.50 & 15.55 & 12.11 & C2S2 \\
\hline T3 & 8.15 & 2.52 & 0.70 & 2.85 & 15.90 & 6.01 & 6.13 & 31.65 & 20.25 & 12.85 & C4S2 \\
\hline T4 & 8.15 & 3.44 & 1.00 & 3.55 & 22.20 & 10.30 & 8.55 & 42.90 & 28.30 & 13.97 & C4S2 \\
\hline $\mathrm{T} 5$ & 8.25 & 4.25 & 1.10 & 3.30 & 29.00 & 13.83 & 11.04 & 53.40 & 36.90 & 15.14 & C4S2 \\
\hline
\end{tabular}

*SAR - Sodium Adsorption Rate; SAR $=\mathrm{Na}^{+} /\left[\left(\mathrm{Ca}^{+2}+\mathrm{Mg}^{+2}\right) / 2\right]^{1 / 2}$ 
mean weight of the discs and leaf dry matter. ILA (LA/NL) was determined based on the leaf area and on the number of leaves per plant (NL). For dry matter data, two plants per plot were divided into leaves, stems and roots and dried at temperature of $65{ }^{\circ} \mathrm{C}$ for three days, in a forced-air oven.

The results were subjected to analysis of variance by $\mathrm{F}$ test at 0.05 probability level, using the statistical program SISVAR (Ferreira, 2011). In case of significance in the effects of the treatments, the data were subjected to regression analysis.
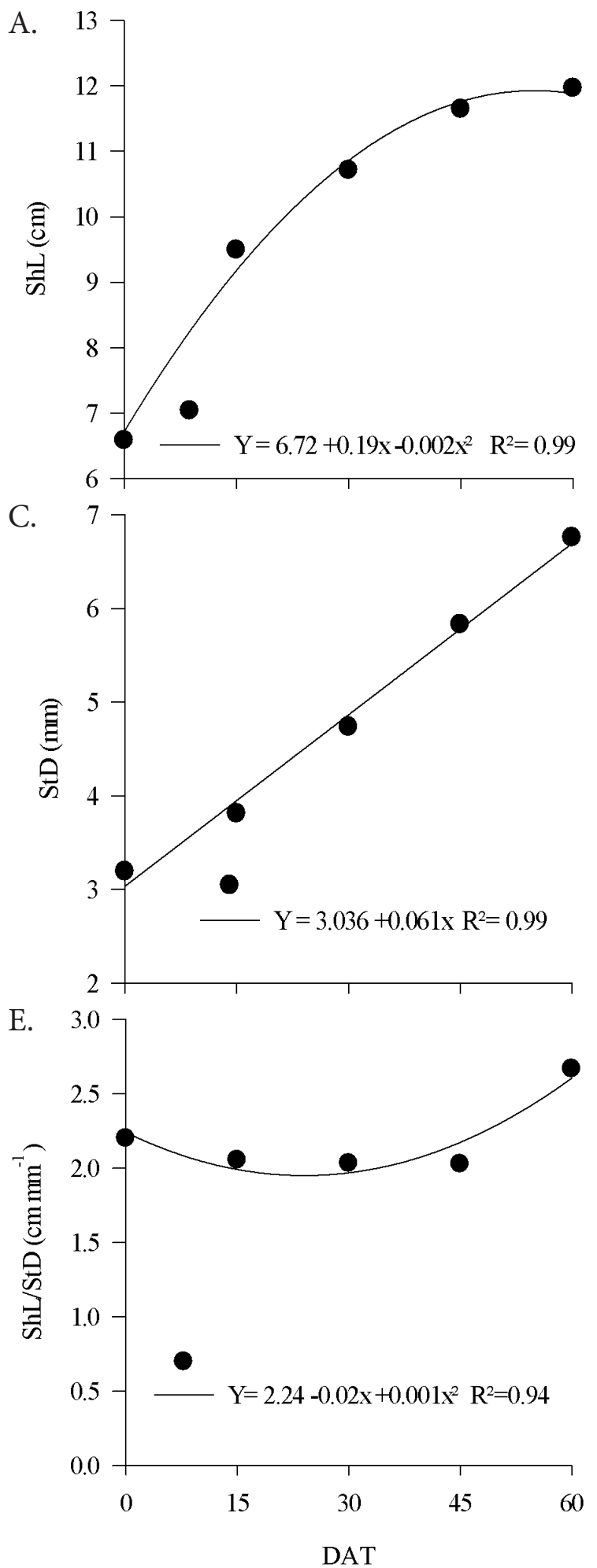

\section{RESULTS AND Discussion}

Quadratic increment was observed in the ShL of Tabebuia aurea seedlings as a function of the evaluation periods (Figure 1A). Although there was effect of the use of wastewater diluted in the irrigation water, the data did not fit to any regression model (Figure 1B). However, this variable was slightly affected by the increment in the concentration of wastewater. Growth inhibition is a direct consequence of the toxicity
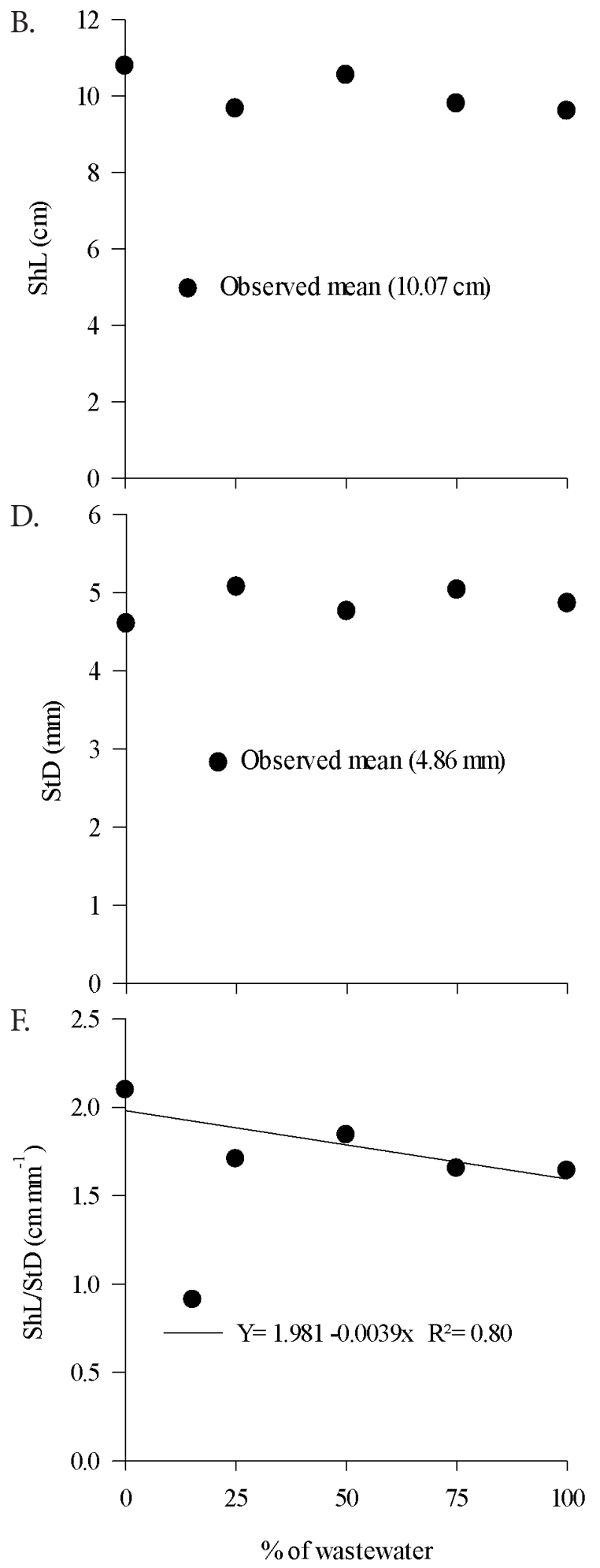

Figure 1. Shoot length - ShL (A and B), stem diameter - StD (C and D) and shoot length/stem diameter ratio - ShL/StD (E and F) of Tabebuia aurea seedlings under irrigation with different concentrations of fish-farming wastewater during (left) and at 60 days (right) after transplantation (DAT) 
and the osmotic effect caused by the salts (Fernandes et al., 2003; Sousa et al., 2011). However, the decrease in ShL did not exceed $10 \%$ for plants irrigated with $100 \%$ fish-farming wastewater, which can be explained by its high concentration of nutrients.

Similar results were obtained by Diniz Neto et al. (2014), who studied the effects of saline water in the soil with bovine biofertilizer and potassium on the initial growth of 'Oiticica' plants (Licania rigida Benth). Under these conditions, the authors noted that the use of water with EC of $4.5 \mathrm{dS} \mathrm{m}^{-1}$ (value close to the EC of pure fish-farming water) reduced plant height by more than $62 \%$; however, when the bovine biofertilizer was added to the soil, this reduction did not exceed $20 \%$. Thus, these authors concluded that the presence of a nutritional source for plants can lessen the damages caused by the use of saline water.

StD (Figure 1C) showed an increasing linear response until 60 DAT; as observed for ShL, StD data (Figure 1D) did not fit to any type of regression, but the saline effect of the irrigation water on this variable was possibly null, due to the beneficial effect of the nutrients present in the water. Compared with the exclusive use of freshwater and despite an increase of more than $3.7 \mathrm{dS} \mathrm{m}^{-1}$ in irrigation water EC composed of $100 \%$ fish-farming wastewater, StD increased slightly more than $5 \%$, which was superior to the values obtained by Cavalcante et al. (2011) with Jatropha (Jatropha curcas L.) and Nunes et al. (2012) with neem (Azadirachta indica A. Juss), who evaluated the use of saline water and a nutrient source on plant growth.

During the evaluation period, the ShL/StD ratio (Figure 1E) decreased until close to 30 DAT, when it started increasing, reaching its maximum value at $60 \mathrm{DAT}$. There was a decreasing linear response of the ShL/StD ratio (Figure $1 \mathrm{~F}$ ) with the increase in wastewater concentration in the irrigation water, with a reduction of approximately 5\%, according to each studied level, which resulted in the total reduction of $20 \%$ in this variable for the highest concentration of wastewater (100\%), compared with plants irrigated with only freshwater. Such behavior shows that stem growth in height is more sensitive to salinity than its growth in diameter.

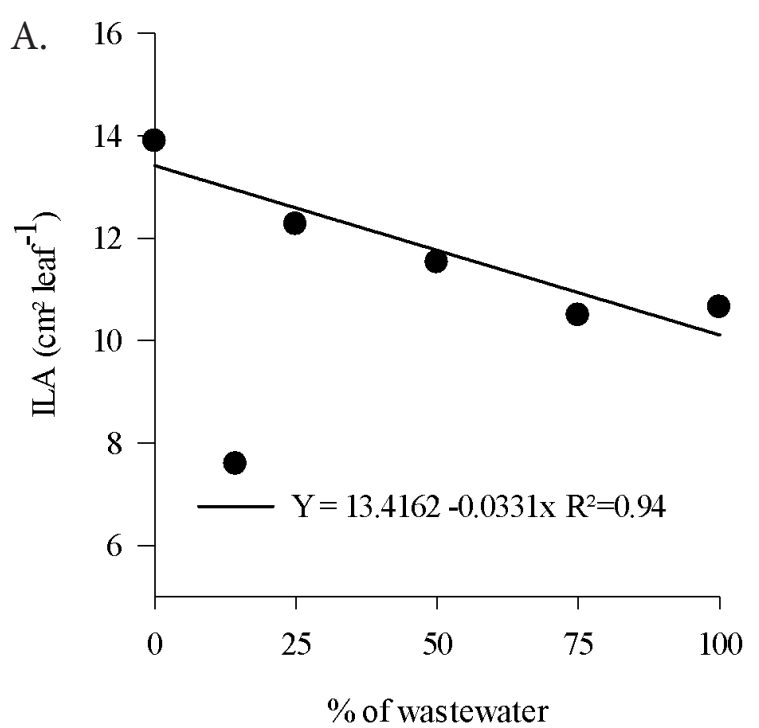

The results of ILA (Figure 2A) fitted to a decreasing linear model in which the wastewater concentrations of $25,50,75$ and $100 \%$ reduced ILA by $6,12,19$ and $25 \%$, respectively, in comparison to irrigation with only freshwater. For LA (Figure $2 \mathrm{~B})$, there was also a decrease as a function of the irrigations with wastewater at the concentrations of $25,50,75$ and $100 \%$, with LA reductions of 12, 22, 29 and 33\%, respectively, compared with plants irrigated with only freshwater.

According to Munns \& Termaat (1986), one of the first responses of a non-halophyte plant when exposed to salinity conditions is the slow growth of leaves, which are considerably sensitive to this problem. In this case, low concentrations of fish-farming wastewater in the irrigation of Tabebuia aurea seedlings must be used; otherwise, the total LA of the seedlings can be drastically reduced.

The effect of water salinity on leaf area can also be observed through the dry matter. LDM data (Figure 3A) fitted to a decreasing linear model and each increment of $25 \%$ in the wastewater concentration negatively affected this variable by $9 \%$. On the other hand, RDM data (Figure 3B) of Tabebuia aurea seedlings revealed that the plant was benefited with increments of 10 and $5 \%$ for the use of the wastewater concentrations of 25 and 50\%, respectively, in the irrigation water. However, when the concentration increased to $75 \%$, this variable decreased by approximately $17 \%$ in relation to the exclusive use of freshwater.

The observed gains in RDM at low concentrations of wastewater can be explained by the high amount of nutrients present in the water, associated with a lower sensitivity of the roots to the saline stress. Munns \& Termaat (1986) explain that root growth is almost always less affected than shoot growth under salinity conditions. These authors also claim that, at low saline levels, root growth may not be affected or even show increments.

The response curve of TDM (Figure 3C) also fitted to a quadratic model and the dilution of $50 \%$ of wastewater caused negative effect of less than $6 \%$ on this variable. Hence, the substitution of half of the irrigation water by fish-farming effluent does not lead to significant losses in TDM. Rocha et al. (2014) observed an increase of $14 \%$ in TDM of Eucalyptus sp. Irrigated

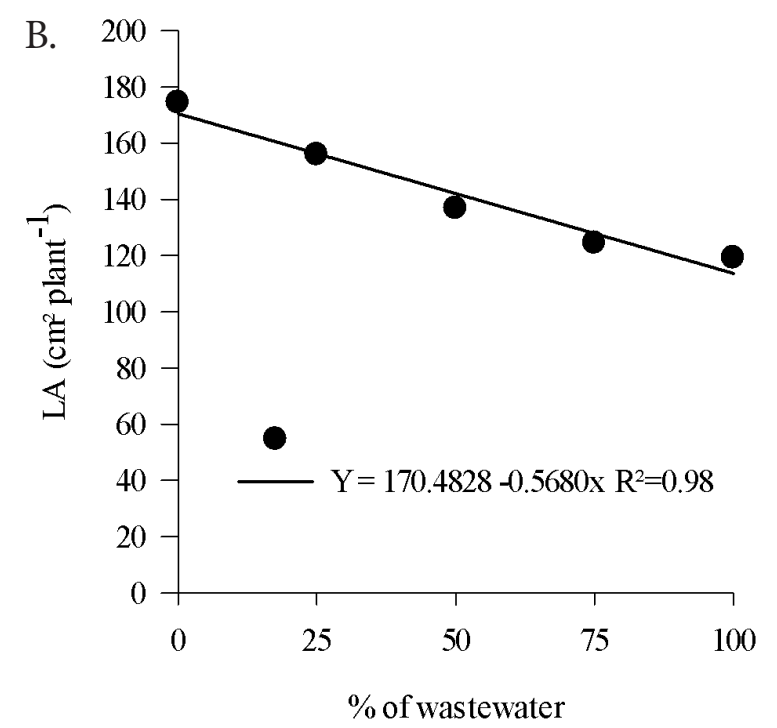

Figure 2. Individual leaf area - ILA (A) and leaf area - LA (B) of Tabebuia aurea seedlings under irrigation with different concentrations of fish-farming wastewater, at 60 days after transplantation 

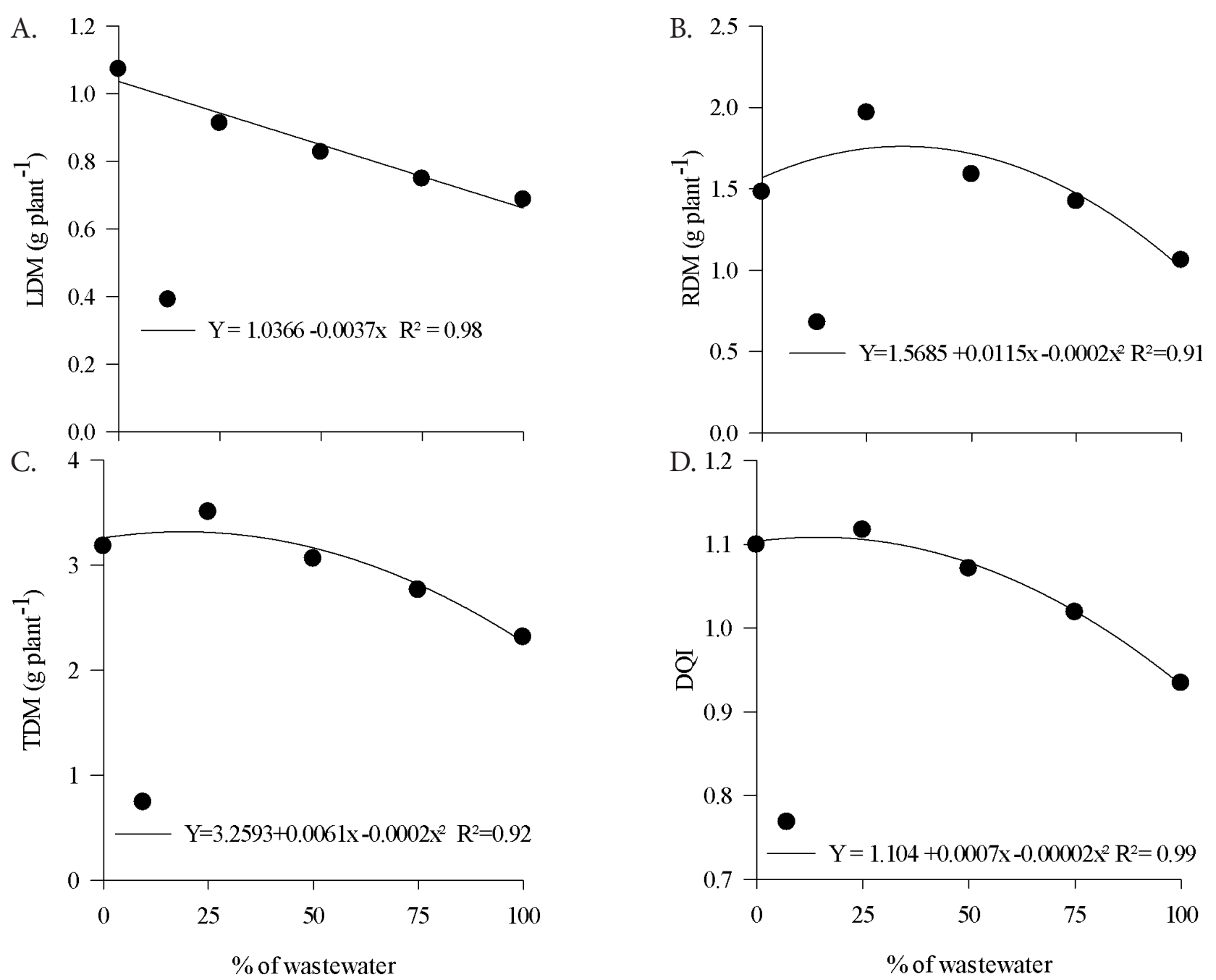

Figure 3. Leaf dry matter - LDM (A), root dry matter - RDM (B), total dry matter - TDM (C) and Dickson quality index - DQI (D) of Tabebuia aurea seedlings under irrigation with different concentrations of fish-farming wastewater, at 60 days after transplantation

with pure, non-saline, fish-farming effluent. However, under the conditions of this study, TDM is affected by approximately $20 \%$ as the wastewater concentration increased to $75 \%$.

The DQI (Figure 3D) of Tabebuia aurea seedlings also showed favorable results for the use of low concentrations of fish-farming wastewater. There was a negative variation of about $1 \%$ when plants were irrigated with the dilution of $50 \%$ of wastewater, which showed EC of $2.52 \mathrm{dS} \mathrm{m}^{-1}$ (Table 1). It is noted that the seedlings were slightly affected by salinity, since Diniz Neto et al. (2014) observed that the quality of Licania rigida Benth seedlings was clearly compromised

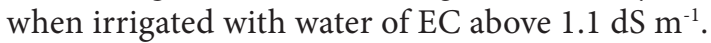

\section{Conclusion}

The reuse of fish-farming wastewater diluted at concentrations of 25 to $50 \%$ is a viable alternative for the irrigation of Tabebuia aurea seedlings and higher concentrations made the production of its seedlings unviable.

\section{Literature Cited}

Bezerra, B. G.; Fideles Filho, J. Análise de crescimento da cultura do algodoeiro irrigada com águas residuárias. Revista Ciência Agronômica, v.40, p.339-345, 2009.
Carmo Filho, F. do; Espínola Sobrinho, J.; Maia Neto J. M. Dados climatológicos de Mossoró: um município semi-árido nordestino. Mossoró: ESAM, 1991. 121p.

Carneiro, J. G. de A. Produção e controle de qualidade de mudas florestais. Curitiba: UFPR/FUPEF, 1995. 451p.

Castro, R. S. de; Azevedo, C. M. da S. B.; Barbosa, M. R. Efeitos de efluente de viveiro de piscicultura e de água de poço na irrigação do tomate cereja, cultivado em diferentes níveis de adubação orgânica. Revista Ciência Agronômica, v.36, p.396-399, 2005.

Cavalcante, L. F.; Rebequi, A. M.; Sena, G. S. A. de; Nunes, J. C. Irrigação com águas salinas e uso de biofertilizante bovino na formação de mudas de pinhão-manso. Irriga, v.16, p.288-300, 2011. http://dx.doi.org/10.15809/irriga.2011v16n3p288

Dickson, A.; Leaf, A. L.; Hosner, J. F. Quality appraisal of white spruce and white pine seedling stock in nurseries. Forest Chronicle, v.36, p.10-13, 1960. http://dx.doi.org/10.5558/tfc36010-1

Diniz Neto, M. A.; Silva, I. de F. da; Cavalcante, L. F.; Diniz, B. L. M. T.; Silva, J. C. A. da; Silva, E. C. da. Mudas de oiticica irrigadas com águas salinas no solo com biofertilizante bovino e potássio. Revista Brasileira de Engenharia Agrícola e Ambiental, v.18, p.10-18, 2014. http://dx.doi.org/10.1590/S1415-43662014000100002

Fernandes, A. R.; Carvalho, J. G. de; Curi, N.; Guimarães, P. de T. G.; Pinto, J. E. B. P. Crescimento de mudas de pupunheira (Bactris gasipaes H.B.K.) sob diferentes níveis de salinidade. Ciência e Agrotecnologia, v.27, p.278-284, 2003. http://dx.doi.org/10.1590/ S1413-70542003000200005 
Ferreira, D. F. Sisvar: a computer statistical analysis system. Ciência e Agrotecnologia, v.35, p.1039-1042, 2011. http://dx.doi. org/10.1590/S1413-70542011000600001

Holanda, A. C. de; Santos, R. V. dos; Souto, J. S.; Alves, A. R. Desenvolvimento inicial de espécies arbóreas em ambientes degradados por sais. Revista de Biologia e Ciência da Terra, v.7, p.39-50, 2007.

Hussar, G. J.; Paradela, A. L.; Jonas, T. C.; Gomes, J. P. R. Tratamento da água de escoamento de tanque de piscicultura através de leitos cultivados de vazão subsuperficial: Análise da qualidade física e química. Engenharia Ambiental, v.2, p.46-59, 2005.

Lorenzi, H. Árvores brasileiras: Manual de identificação e cultivo de plantas arbóreas do Brasil. 3.ed. Nova Odessa: Instituto Plantarum, 2000. 373p.

Munns, R; Termaat, A. Whole-plant responses to salinity. Australian Journal of Plant Physiology, v.13, p.143-160, 1986. http://dx.doi. org/10.1071/PP9860143

Nunes, J. C.; Cavalcante, L. F.; Lima Neto, A. J. de; Rebequi, A. M.; Diniz, B. L. M. T.; Gheyi, H. R. Comportamento de mudas de nim à salinidade da água em solo não salino com biofertilizante. Revista Brasileira de Engenharia Agrícola e Ambiental, v.16, p.1152-1158, 2012. http://dx.doi.org/10.1590/ S1415-43662012001100002
Oliveira, H. do V. de; Bezerra Neto, F.; Azevedo, C. M. da S. B.; Lima, C. B. e; Gurgel, G. C. de S. Alterações nas características químicas de um Argissolo Vermelho-Amarelo irrigado com efluente de piscicultura, em ambiente protegido. Revista Agro@mbiente On-line, v.3, p.9-14, 2009.

Rocha, S. A.; Garcia, G. O.; Lougon, M. S.; Cecílio, R. A.; Caldeira, M. V. W. Crescimento e nutrição foliar de mudas de Eucalyptus sp. irrigadas com diferentes qualidades de água. Revista de Ciências Agrárias, v.37, p.141-151, 2014.

Silva, F. A. de M.; Melloni, R.; Miranda, J. R. P. de; Carvalho, J. G de. Efeito do estresse salino sobre a nutrição mineral e o crescimento de mudas de aroeira (Myracrodruon urundeuva) cultivadas em solução nutritiva. Cerne, v.6, p.52-59, 2000.

Sousa, A. B. O. de; Bezerra, M. A.; Farias, F. C. Germinação e desenvolvimento inicial de clones de cajueiro comum sob irrigação com água salina. Revista Brasileira de Engenharia Agrícola e Ambiental, v.15, p.390-394, 2011. http://dx.doi. org/10.1590/S1415-43662011000400010

Souza, M. S. de; Alves, S. S. V.; Dombroski, J. L. D.; Freitas, J. D. B. de; Aroucha, E. M. M. Comparação de métodos de mensuração de área foliar para a cultura da melancia. Pesquisa Agropecuária Tropical, v.42, p.241-245, 2012. http://dx.doi.org/10.1590/S198340632012000200016 